\title{
貯槽等における爆発・火災の予測と防止 ートラブル対処作業に関連してー
}

八島 正 明*1

\begin{abstract}
タンクやサイロなどの貯槽では, 貯蔵した化学物質が発熱して発火, 爆発したり，火災が発生したりする 危険性がある．異常発生時には，現場作業員が緊急排出や消火等のトラブル対処作業を行う際に被災すること もある．最悪の場合，小康状態が続き，大勢が集まった時に大きな爆発が発生することもある．内部が見えに くい貯槽等ではセンサーなどを使って状況を的確に把握し, 爆発や火災に至る進展事象を予測し, 避難のタイ ミングを計るなど, トラブルに適切に対処することが求められる. 本稿では, 貯槽等における爆発・火災の事 例を挙げ，トラブル対処作業に関連して爆発と火災の予測と防止の方策を考察する.

キーワード: 非定常作業, 消火, 粉じん爆発, 粉体火災, ごみ固形化燃料, 化学工場, 貯槽
\end{abstract}

\section{1 はじめに}

貯槽やサイロなどで異常な温度上昇や煙の発生などの トラブルが認められると，マニュアルなどに従ってすぐ に緊急対応がとられる. トラブル対応とは保守・定期補 修などの非定常作業の一つである. 厚生労働省では, 近 年の化学工場の災害 $\left.{ }^{1.4}\right)$ を受けて, 化学設備の非定常作 業の安全衛生対策のガイドラインを見直している5゙。 た, 事業場では, 公設消防隊か椡着までは自衛防災組織 の隊員が適切に対処し，初期消火などを行わなければな らない. 最近, 石油コンビナートの災害向けの教育テキ ストが消防庁より刊行されているす ${ }^{0}$.

本稿では, 貯槽等に打ける爆発・火災の事例, 特に消 火作業中に作業員が被災した事例を挙げ，トラブル対処 作業に関連して爆発と火災の予測と防止の方策を考察す る.

\section{2 近年の化学工場での重大災害，非定常作業における 労働災害}

1）大規模施設の貯槽等における爆発・火災

2011年11月 13 日 15 時すぎに発生した塩化ビニルモ ノマーの製造施設の火災1) では，同日 3 時過ぎに 2 系列 ある工程の $\mathrm{A}$ 系の緊急放出弁が故障した後, 工程 $\mathrm{A}$ 系の ロードダウンに対応していたところ, 鉄さび等を触媒と するエチレンジクロライド生成反応が暴走し, 塩酸塔還 流槽付近で爆発打よび火災が発生した。この火災では熟 練技術者の不足が事故原因の一つに挙げられ, 事故発生 後の事象進展に関する想像力の不足も反省となった.

2012年 4 月 22 日に発生したレゾルシン製造施設での 火災 ${ }^{2}$ は, 前日 23 時すぎに蒸気供給プラントのトラブ ルで緊急停止作業を行っていたところ，2時すぎに爆発， 火災が発生し, 約 6 時間後に 2 回目の爆発があった. 直 接の原因としては緊急停止作業中に, 冷却の増強を目的

原稿受付 2018 年11月27日（Received date: November 27, 2018） 原稿受理２019年 1 月 22 日 (Accepted date: January 22, 2019) J-STAGE Advance published date: February 18, 2019

*1 労働安全衛生総合研究所化学安全研究グループ

連絡先 : ₹204-0024 東京都清瀬市梅園 1-4-6

労働安全衛生総合研究所化学安全研究グループ 八島正明

E-mail: yashima@s.jniosh.johas.go.jp

doi: 10.2486/josh.JOSH-2018-0017-SHI
としてインターロックを解除して通常の循環水冷却に切 り替えたが, そのことで窒素供給が停止し, 酸化反応器 内の液相のかくはんが停止した，それにより反応器上部 にある過酸化物の冷却ができず温度が上昇し, 暴走反応 に至った。

以上の事例を要約すると, トラブル発生後の事象進展 に的確に対処すれば，事故災害の拡大を未然に防げたと 考えられる。

\section{2）主な非定常作業における労働災害}

化学設備の事故災害の割合は定常作業が約 $40 \%$, 非 定常作業が約 $60 \%$ で，非定常作業をさらに細かい作業 に分けてみると，次のような割合になっている5).

・保全的作業（非定常作業のうち57\%)

・トラブル対処作業（同28\%）

・移行作業 (同 $5 \%$ )

・試行作業（同2\%)

・そのほかの作業（同 $8 \%)$

本稿で取り上げるトラブル対処作業について，運転や 作業中の異常事象・緊急を要する事態の発生は, あらか じめ想定されるものであれば，決められた手順で対処す ればよい. しかし，トラブル発生は予測が難しく，操業 以来初めて経験する事態であったりすれば，その場での 適切な判断で対処することは難しいといえる. 次節以降 で述べるが，本作業は，消火作業など現場に人が集まっ たときに被災するケースが最も多い作業である.

1991年～1996年の期間の化学設備における非定常作 業における労働災害の発生状況について調べられたも の7)によると, 保全的作業は 140 件, トラブル対処が 47 件, 保全とトラブル対処が 19 件, その他が 7 件であった. トラブル対処に関する爆発と火災は6件だけで，むしろ 機械へのはさまれ・巻き込まれ, 手の負傷の災害が多か った. しかし, 事業場で爆発や火災が一度発生すると, 重篤な災害になりやすく, 経済活動や周辺地域に影響を 及ぼし，社会的影響が大きくなりやすいことを理解して おく必要がある. 特に, 素材産業での爆発や火災の影響 は深刻となる。 


\section{3 消火作業中の災害事例 ${ }^{8)}$}

表 1 に厚生労働省の web サイト「職場のあんぜんサイ 卜」9)の労働災害事例で「消火作業」をキーワードに検 索した一例を示す．現場作業員が消火を試みたところ粉 じん爆発が発生したり, 火傷, CO中毒, 酸欠を負った りしていること, 着衣着火によって火傷から死亡に至る 事例があることがわかる.

表 2 に労働安全衛生総合研究所の web サイト「爆発火 災データベース $\perp^{10)}$ で消火作業をキーワードに検索した 結果の一例を示す. 粉じん爆発では, 消火作業中に事故 が拡大することがしばしばみられる（番号 1３，6）. 消火作業で水を使用したことによって水素が発生し, 被 害が拡大した事例もある（番号3と6).

燃焼方式の乾燥設備, ボイラーでは失火の後の再点火 の際にプレパージが不適切であったり, 付帯設備に動作 不良があったりすると再点火時に爆発が発生することが ある (番号 4$)$.

\section{4 粉じん爆発・粉体火災と消火作業}

1) 粉じん爆発

粉じん爆発とは, 可燃性の粉体が浮遊し, 空気中の粉 じん濃度が燃焼範囲にあるとき，なんらかの着火源によ って燃焼を開始し，火炎が伝ぱする際の体積膨張，すな わち急激な圧力上昇や発熱によって周囲に被害を及ぼす 現象のことをいう，粉じん爆発を生じる爆発下限濃度は 粉の種類，大きさによって異なるが， $50 \sim 200 \mathrm{~g} / \mathrm{m}^{3}$ の

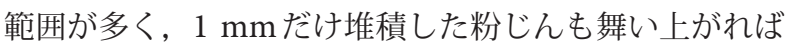
粉じん爆発を生じる原因になるといわれる.

金属（粉）の火災に注水は厳禁である。しかし，過去 には消火のために注水を行った事例は多い. 注水によっ て粉を舞い上げて粉じん爆発を生じたり，水の急激な蒝 発により火炎が大きくなったり, また水素が発生したり する. 水素は拡散しやすいので, 開放空間では堆積粉か ら離れると水素の爆発の危険性は低下するが，閉じた空 間が存在すると水素が滞留し, 危険性は増す。

表 1 消火作業中の主な労働災害事例（「職場のあんぜんサイト」より）

\begin{tabular}{|r|l|}
\hline \multicolumn{1}{|c|}{ 整理番号 } & \multicolumn{1}{c|}{ 表 題 } \\
\hline 1077 & $\begin{array}{l}\text { フェノール樹脂の合成反応工程で, 異常反応の非常処置作業中に未反応の高濃度フェノール液が皮膚に接触して化学 } \\
\text { 火傷 }\end{array}$ \\
\hline 100137 & 木粉で製造する合板の工場で粉じん爆発 \\
\hline 100546 & フェロマンガン粉の乾燥工程において, 異常が発生したため停電中, 乾燥機内で粉じん爆発 \\
\hline 101121 & 塗装工場で発生した火災の消火作業中に焼死 \\
\hline 101147 & 自動車部品製造工場で発生した火災の消火活動で一酸化炭素 (CO)) 中毒になる \\
\hline 101225 & マグネシウム成形機で発生した火災の消火活動中, 煙を吸い込む \\
\hline 101274 & 船倉内で鉱石の搬出作業中に, 作業者1人及び救助に向かった2人の作業者が酸素欠乏症で死亡 \\
\hline
\end{tabular}

表2 消火作業中の事故災害の例（労㗢安全衛生総合研究所の「爆発火災データベース (第5次)」より)

\begin{tabular}{|c|c|}
\hline 番号 & 事故の概要 \\
\hline 1 & $\begin{array}{l}\text { とうもろこし外皮の乾燥設備の内部から出火, 炭酸ガス消火器を手動で全開操作したところ, 火炎が外に吹き出して, } \\
\text { 消火活動中の作業者ら計 } 11 \text { 名が火炎により被災した. (死傷 } 11 \text { 人, うち死亡 } 0 \text { 人) }\end{array}$ \\
\hline 2 & $\begin{array}{l}\text { オガ炭工場において, 釜の煙突から排出された火の粉が平常運転中の同工場トタン屋根上の堆積木粉に着火して火災 } \\
\text { となった. 消火作業中に消火器の噴射で然え上がって爆燃したため, 消火作業中の被災者が火傷を負った. (死傷 } 4 \text { 人, } \\
\text { うち死亡 } 1 \text { 人) }\end{array}$ \\
\hline 3 & $\begin{array}{l}\text { アルミニウム屑よりアルミニウム粉を製造している工場で, グラインダーの火花が飛んで床上のアルミニウム粉に火 } \\
\text { がついて火災となった. 消火しょうと水をかけたところ, 堆積していたアルミニウム粉が飛散し, 粉じん爆発と一部 } \\
\text { はアルミニウムの水との反応で発生した水素の爆発が起こった. (死傷 } 4 \text { 人, うち死亡 } 2 \text { 人) }\end{array}$ \\
\hline 4 & $\begin{array}{l}\mathrm{A} \text { 重油を使用するボイラーを自動制御によって消火工程を実施した. しかし, 何らかの原因で燃料系統の電磁弁配線 } \\
\text { が電磁弁キャップに接触し，通電状態のままとなったため, 電磁弁が開き燃料噴射ポンプが稼働して } \mathrm{A} \text { 重油がボイラ } \\
\text { 一の炉内に送られて気化してしまいい, 点火用パイロットバーナーにより爆発した. (死傷 } 0 \text { 人, うち死亡0人) }\end{array}$ \\
\hline 5 & $\begin{array}{l}\text { 精米施設の精米用ホッパー脇において, 積み置きした空の紙袋の火災をたまたま発見し, } 2 \text { 名が消火作業中, 近くに } \\
\text { 積んであった玄米の袋に飛び火して玄米のはいが崩壊し, 下敷きになった } 1 \text { 名が火炎で火傷を負い約 } 3 \text { 週間後に死亡 } \\
\text { した. 火災の出火原因は不明. (死傷 } 1 \text { 人, うち死亡 } 1 \text { 人) }\end{array}$ \\
\hline 6 & $\begin{array}{l}\text { 金属粉砕工場において, マンガン湿式粉砕設備で火災があり, 設備を停止して消火した. 集じんダクトを点検したと } \\
\text { ころ温熱じたの゙災と考え, 注水のため点検孔を開放する直前, 乾燥機が爆発し点検孔付近にいた } 2 \text { 名が死亡 } \\
\text { した. 原因は, 乾燥機内の湿ったフェロマンガン粉から発生した水素が集じん機を止めていたので滞留し, 湿潤状態 } \\
\text { のフェロマンガン粉が自熱して自然発火, 水素の燃焼により乾燥機内の粉じんが舞い上げられ粉じん爆発を起こ } \\
\text { したとみられる. (死傷 } 2 \text { 人, うち死亡 } 2 \text { 人) }\end{array}$ \\
\hline
\end{tabular}




\section{2）粉体火災}

粉が堆積した状態で舞い上がらずとも, 何らかの原因 で着火した場合には燃え拡がりが見られる。燃え拡がり は着火した位置の違いによって層表面に沿って燃え拡が る場合と堆積層内で燃え拡がる場合がある。貯槽やサイ 口などでは堆積層の内部で自然発火によって燃え拡がり が生じることが多い（図1)。このときの燃焼の形態と しては, 無炎燃焼を呈するくん焼となる. 農産物, 飼料, 木粉（おがくず），プラスチック（高分子）などの有機 物のくん焼状態における燃焼温度は 550 から $750^{\circ} \mathrm{C}$ 程度 で, 燃え拡がりの速度は $0.1 \mathrm{~mm} / \mathrm{min}$ 程度である. ただ し, 粉体の径が大きい場合やペレット形状（直径 10〜 $20 \mathrm{~mm}$, 長さ 20〜 50 mm）の場合は, その速度は一析大 きくなる，燃え拡がり速度は粉体の大きさ，堆積層の熱 伝達特性, 堆積層内の空隙, 通気性, 酸素濃度などに依 存する．層内が密閉に近い状態であれば，酸素が無くな りいずれ燃焼反応が停止する。しかし，開口部があって 新鮮な空気の流入がある状態であったり, 堆積層が崩落 して空陌が増加したりすると, 無炎から有炎に変化し, 速く燃え拡がるようになる. 可燃性の熱分解ガスが局所 的に滞留していると, 爆発の可能性もある. このほか, 粉体火災の特徴などを以下に示す。

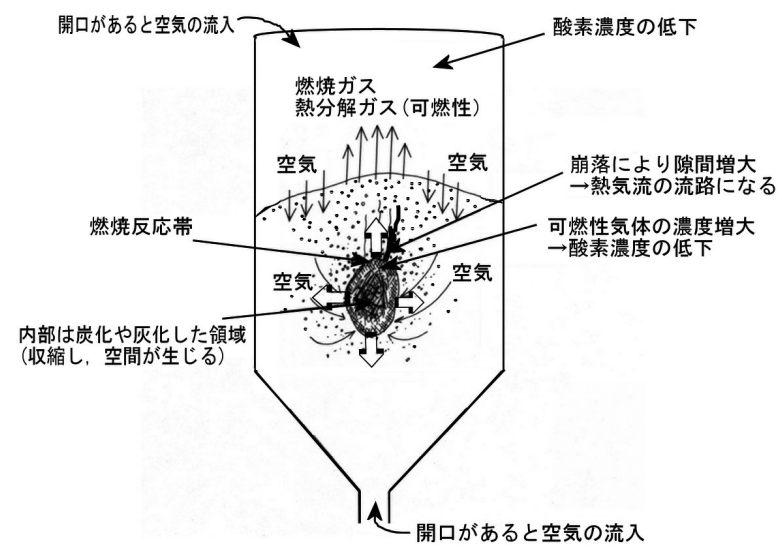

図 1 堆積層内部の燃え拡がりの様子 （内部で発火した場合）

・層内で蓄熱から発火した場合は，火災が発見されるま で時間を要する場合が多い。灭の発見は，ほとんど の場合，煙や臭いの発生による，COセンサーを設け ているサイロもある

- 着火源としては発熱を伴う反応, 高温熱面, 飛び火（燃 焼粒子）が代表例である.

- 粉体火災では爆発に比べ, 有害性ガス, 可燃性の熱分 解ガスを多く発生する．このときの煙は，すすや水蒸 気だけではなく, 可燃性の熱分解ガス (蒸気) である ことも多く，滞留によってガス爆発が発生する危険性 がある.

・燃焼の過程が変化しやすい。災 $\rightarrow$ 爆発へ，爆発 $\rightarrow$ 火 災へ遷移

・粉体サイロ内でのくん焼の消火には長時間要する場合
があり，海外の消火の好事例では，小麦子すま（小麦 の表皮）ペレットのサイロ火災に扔いて，窒素を底部 から，二酸化炭素を頂部から投入し 3 週間かけて鎮火 した例がある ${ }^{11}$. 燃え拡がりはゆっくり進行するので, 消火に拙速は禁物である.

\section{5 予測・退避距離}

\section{1）暴走反応の予測}

貯槽内の温度変化について，十分な性能を有する温度 計を適切な位置に設置していれば，モニタリングによっ て暴走反応開始までの時間は予測できる可能性がある. そのためには貯蔵する物質の融点, 沸点, 熱伝達特性, 比熱などの物性值のほか, 発熱開始温度, 発熱量, 最大 加熱発熱速度などを予め把握し, 起こりえる暴走反応を モデル化している必要がある。しかし, 温度を正しく測 定できなかったこと, 冷却装置の不備や方法の不適切さ, 扱っている物質・反応の危険・有害性の情報の不足など 諸々の原因により，トラブルに適切に対処できなかった 事例は多い，取り扱う物質に関する情報がSDSに全て 記載されているわけではないため，文献を調査したり， 実測してデータを収集したりしなければならない。さら に，混合危険性などはSDSでの情報は不十分であるこ とが多く，タンク内で副生しうる物質や，構造材，混入 物（さび等）との反応も考慮し，実測する必要がある.

\section{2) 退避距離}

法令では可燃物の保管量によって, 保安距離, 離隔距 離などが定められているが，これらは周辺施設の被災防 止や火災予防の観点から定められているものであり，作 業員の被災などは考慮されていない，防災アセスメント 指針 ${ }^{12)}$ によると，算定条件を定めることで影響距離が 求められる. 米国の危険物輸送に打ける緊急対応ガイド

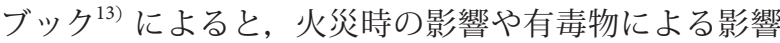
を考慮して，危険・有害物の特性によって退避距離がリ スト化されている，近隣住民等にはもちろんのこと，緊 急時に対応する作業員等が身を守る行動をとる際，その ような情報があると参考になるはずである.

大規模な化学工場を除くと, 危険・有害性の物質を扱 う立地としては十分な距離を確保できない事例も多い. 数 $100 \mathrm{~m}$ 離れ保安距離が十分あっても, 爆風によって付 近のガラス空が割れること䘞 で被災する可能性もある ので，避難する場所はよく検討しておく．

\section{6 燃焼ガスの有害性・消火確認}

\section{1）燃焼ガス}

火災時には有害な燃焼ガスが発生しやすい。一般建物 による火災実大実験に扔いて, $\mathrm{CO}, \mathrm{CO}_{2}, \mathrm{O}_{2}$ 濃度など 分析結果によると, 次のことが明らかになっている15).

・燃焼に伴い, $\mathrm{O}_{2}$ 濃度が低下し, $\mathrm{CO}, \mathrm{CO}_{2}$ 濃度, 温度, 煙濃度が増加すること。

・ $\mathrm{CO}$ に対する $\mathrm{CO}_{2}$ の生成量は, 閉空時よりも開空時の ほうが非常に大きいこと.

・火災室またはその付近では，人間にとって非常に厳し

Vol. 12, No. 1, pp. 67-71, (2019) 
い状況にあり，COは $5 \%$ 以上， $\mathrm{CO}_{2}$ は $15 \%$ にをなり $\mathrm{O}_{2}$ 濃度は2〜3\%にまで低下すること，このときの火 災室内の温度は $700 \sim 800^{\circ} \mathrm{C}$ に達すること.

・火災室からかなり離れ, 火の熱の影響をほとんど受け ない場所で, 有害ガス, 例えば, COの濃度が高くな ること.

ここで理解しなければならないのは，火災の発生場所 から離れていても CO中毒の危険性があるということで ある. 例えばポリエチレン, ポリウレタンなどの高分子 の燃焼 ${ }^{16)}$ では, 有害な CO (可燃性ガスでもある) が大 量に発生する.

\section{2）消火確認，残火処理など}

工場の爆発や火災では取り扱う原料や製品の可燃物だ けでなく, 設備も燃えるため, 燃焼生成物は多岐にわた るはずである. 規模が大きくなると不完全燃焼も生じや すい，もちろん燃焼によって周囲の酸素が消費されるの で, 付近は酸素が少ない状況となる. 消火の確認のため に装置内部に侵入する際には, 酸欠や一酸化炭素などの 有害ガスによる中毒に注意が必要である。また, 装置の 扉を開けたことで, 新鮮な空気の流入で再燃したり, 粉 が舞い上がって粉じん爆発が生じたりする可能性があ る. 残り火の確認にはガス検知警報器を携行し, 必要な 保護具を身に着けて慎重に構えて人り, 不用意に装置の 扉を開かないほうがよい。

携帯型のガス検知警報器のしきい值は, 一般に爆発下 限濃度の $1 / 4$ に設定されることが多い. アラームが鳴つ たときは, 自身の動作で人体に帯電し, 静電気が着火源 となる危険性が高まることもある. なぜなら, 空間のガ 又濃度は不均一で, 局所的には爆発範囲内に達している 可能性があるためである. 固定型のガス検知警報器のア ラームが鳴った場合は, まずは離れた場所で状況を確認 し，不用意に現場に駆け付けないほうがよい.

\section{1）基本事項}

\section{7 トラブル対処}

貯槽等のトラブル対処には内部の異常を検知するため の計測センサー, モニタリングが必要となる。 そして, 異常を検知し, 適切にトラブルに対処するための, 緊急 対応マニュアルが必要となる. 貯槽やサイロなどで異常 な温度上昇や煙の発生などのトラブルが認められると, このマニュアルなどに記載された現場で行なうべき作業 手順に従って, すぐに関係機関への連絡を始めとした緊 急対応がとられる ${ }^{17-18)}$.

表3は貯槽等を含む化学設備等に扔けるトラブル対処 に関する必要事項を示す.いずれも重要な項目であるが, 本稿では, g) の事象を正確に把握すること, の重要性 を取り上げた．これは,適切なトラブル対処を行うには, 「事前に予測できていること」が必要と考えるためであ る. j）のタイムリーな意思決定については, 広瀬の文 献 ${ }^{19)}$ から引用する：「生命に対する危険の大きさが, 行 動の適否を決める. 危険が小さい場合には, 何もしない で様子見をしておいたほうが，あわてて何か大それたこ
とをするよりも安全な場合がある. (中略) 重要なのは, 事態の危険性を客観的に評価するための知性と, 危険度 の評価から導かれた結論を, 果断に実行するための勇気 である」. 事前に予測できていれば, 冷静に対処できる.

\section{2）現象進展の把握のために}

貯槽を含む化学設備等では取り扱う化学物質の物性, 危険性・有害性を把握し，機器・設備，プロセス全般を 把握しておく必要がある. 表4に貯槽等における爆発・ 火災の防止策を示す．取り扱う物質の反応性，発熱，爆 発，火災などの特性を予め把握していれば，トラブル対 処に適切に対応できるはずである.

表3 貯槽等を含む化学設備等におけるトラブル対処に関す る必要事項

a) 異常事象の発端を正しく理解する. アラームの洪水に対してランク付けを行う.

b) 計測機器の指示のずれを適切に理解する. プロセスの特性の把握, 運転条件の適切な調整, 誤操作の 防止, 異常発生の判断

c) 緊急停止の操作手順を明確にする. 停止の判断の明確化, 権限, 誤操作の防止, 制御盤の誤操 作後の対応方法

d) 緊急停止させる設備とその影響を理解する. 安全装置の電源系統, 制御系の分離, 安全な場所での操作

e）適切な保護具を準備する. 呼吸用保護具の選定, 安全帯, 手袋の使用

f）プロセス流体の緊急排出を行う際のバルブ操作, 誤操作の 防止

g) 事象を正確に把握する. 爆発，火災，漏えいなどの理解，進展事象の予測

h) 対処すべきチームを構成する. リーダーの指揮統制, 情報の共有, 単独行動の防止, 作業 の指名

i）想定外のトラブルにも対処する. 対応訓練の実施, 訓練シミュレータ活用, 問題と解決の反 復学習, 個々人の高い能力（知識, 経験, 日々の観察（五 感), 洞察, 機転, コミュニケーション, 発声, 体力, 精 神など)

j）タイムリーな意思決定を行う.

表4 貯槽等における爆発・灭災の防止策

a) 取り扱う物質の物性, 危険・有害性の把握
b) 発熱開始温度, 発熱量, 最大加熱発熱速度などを予め把握
し, 起こりえる暴走反応のモデル化
c) 取り扱う物質に関する情報がSDSに全て記載されているわ
けではないため, 文献調査, 実測によるデータ収集
混合危険性などはSDSでの情報は不十分であることが多
く, タンク内で副生しうる物質や, 構造材, 混入物（さび等）
との反応も考慮し, 実測する
d) 反応, 燃焼, 爆発, 火災, 蒸気雲爆発, 漏えいなどの事象
の理解
e) 機器・設備の理解
f) プロセスの運転条件, 作動環境の理解
g) 貯蔵量や漏えい量に対する晾響度の評価
h) 安全な距離, 退避までの時間
i) 抑制, 防護, 被害の局限化を図る措置




\section{8 おわりに}

本稿では, 非定常作業における労㗢災害としてトラブ ル対処作業を取り上げた.

(1)トラブル対処作業での災害は爆発や火災よりも，はさ まれ・巻き込まれ, 墜落・転落の割合が高い. 爆発や 火災の割合は低いものの, 一度発生すると, 重篤な被 害, 経済活動や周辺地域に及ぼす影響など, 社会へも たらす影響が大きくなりやすい.

(2)トラブル対処として, 消火作業中に作業員が被災した 事例を調べ，検討を加えた.

(3)貯槽に保管されることが多い粉体について，粉じん爆 発と粉体火災について，消火の視点で概説した。

(4)火災が発生すると有害な燃焼ガスが発生すること, 火 災が起きている場所から離れていてもCOなどは高い 濃度になる可能性を説明した。

(5)貯槽等における爆発・火災の防止策を示した。

化学工場に限らず産業現場の中には, 適切に対処した ことで大きな事故や災害にならずに済んだ，部外の者が 知らないような好事例を有している事業場もあろうかと 思われる. 労働安全衛生総合研究所では, 爆発・火災・ 漏えい等の観点から事故対応マニュアル作成に役に立つ 情報を収集していきたい。

\section{文献}

1）清弘光生. 東ソー株式会社南陽事業所において発生した 火災. 火災. $2014: 64$ (3) : 2-7.

2）黒元一夫. 三井化学株式会社岩国大竹工場において発生 した火災. 火災. $2014: 64$ (3)：8-13.

3）塚原昌尚．株式会社日本触媒姫路製造所に打いて発生し た火災. 火災. 2014：64（3）：14-19.

4）中村順. 化学工場火災3例の発生原因. 火災, 2014:64(3): 14-19.

5）化学設備の非定常作業における安全一「化学設備の非定 常作業に打ける安全衛生対策のためのガイドライン」の 見直しに関する調查研究報告書一。中央労㗢災害防止協 会. 平成27（2015）年3月.
6）自衛防災組織等の防災要員のための 標準的な教育テキス 卜. 自衛防災組織等の教育・研修のあり方調查検討会. 総務省消防庁. 平成30（2018）年3月.

7）労㗢省安全衛生部安全課編. 化学設備の非定常作業の安全 ガイドラインと解説. 中央労働災害防止協会. 52-67, 1998.

8）八島正明. 粉を扱う工場でみられる爆発火災一消火活動 に関連して一。炎災. 2016：66（5）：25-30.

9）職場のあんぜんサイト，厚生労働省. http://anzeninfo. mhlw.go.jp/

10）爆発火災データベースの公開（第5次）。労偅安全衛生総 合研究所. https://www.jniosh.go.jp/publication/houkoku/ houkoku_2018_02.html.

11) Eckhoff, R. K. .Dust Explosion in the Process Industries Third Ed.,Gulf Professional Publishing,2003:10.

12）石油コンビナートの防災アセスメント指針．消防庁. 2013. http://www.fdma.go.jp/neuter/about/shingi_kento/ h2 4 / sekiyu_ eikyohyoka/ houkokusho/ houkokusho_ assessment.pdf

13) Emergency Response Guidebook (ERG) 2016. United States Department of Transportation (DOT). https:// www.phmsa.dot.gov/hazmat/erg/erg2016-english.

14) TNO. Yellow Book: Methods for calculation of physical effects. CPR 14E: 2005.

15）日本火災学会編. 火災便覧（第4版）。共立出版. 2018 ： 355-384.

16）森本高克．高分子の燃焼生成ガスの組成．高分子．1973: 22 (253) : 190-195.

17）井上求. ごみ処理施設の火災と爆発事故対策（その5）消 防機関, 初期消火及び連携。廃棄物。2012：38（12）: pp.38-39.

18）井上求.ごみ処理施設の火災と爆発事故対策（その6）事 故対応マニュアルと訓練抢よび対応手順の有効性評価. 廃棄物. $2013 ： 39$ (4) : 40-41.

19）広瀬弘忠. 人はなぜ逃げ遅れるのか，集英社新書。 $2004: 167-169$ 